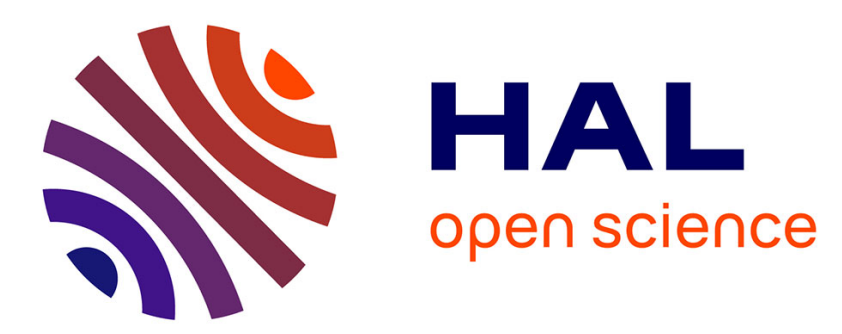

\title{
Correction to "Thermal decomposition of carbonates in fault zones: Slip-weakening and temperature-limiting effects"
}

\author{
Jean Sulem, Vincent Famin, H. Noda
}

\section{- To cite this version:}

Jean Sulem, Vincent Famin, H. Noda. Correction to "Thermal decomposition of carbonates in fault zones: Slip-weakening and temperature-limiting effects". Journal of Geophysical Research: Solid Earth, 2009, 114 (B6), pp.B06311. 10.1029/2009JB006576 . hal-01241170

\section{HAL Id: hal-01241170 \\ https://hal.univ-reunion.fr/hal-01241170}

Submitted on 24 Oct 2016

HAL is a multi-disciplinary open access archive for the deposit and dissemination of scientific research documents, whether they are published or not. The documents may come from teaching and research institutions in France or abroad, or from public or private research centers.
L'archive ouverte pluridisciplinaire HAL, est destinée au dépôt et à la diffusion de documents scientifiques de niveau recherche, publiés ou non, émanant des établissements d'enseignement et de recherche français ou étrangers, des laboratoires publics ou privés. 


\title{
Correction to "Thermal decomposition of carbonates in fault zones: Slip-weakening and temperature-limiting effects"
}

\author{
J. Sulem, V. Famin, and H. Noda \\ Received 28 April 2009; published 19 June 2009.
}

Citation: Sulem, J., V. Famin, and H. Noda (2009), Correction to "Thermal decomposition of carbonates in fault zones: Slip-weakening and temperature-limiting effects,” J. Geophys. Res., 114, B06311, doi:10.1029/2009JB006576.

[1] In the paper "Thermal decomposition of carbonates in fault zones: Slip-weakening and temperature-limiting effects" by Sulem and Famin (Journal of Geophysical Research, 114, B03309, doi:10.1029/2008JB006004, 2009 ), the mass of $\mathrm{CaO}$ produced in the chemical reaction of calcite decomposition (decarbonation) $\mathrm{CaCO}_{3} \rightarrow$ $\mathrm{CaO}+\mathrm{CO}_{2}$ was neglected. Following a remark of $\mathrm{H}$. Noda (private communication, 2009), this term can be taken into account in the mass balance of the solid phase and equation (5) of Sulem and Famin is changed as follows:

$$
\frac{\partial n_{d}}{\partial t}=-\frac{1}{\rho_{\mathrm{CaCO}_{3}}} \frac{\partial m_{\mathrm{CaCO}_{3}}}{\partial t}-\frac{1}{\rho_{\mathrm{CaCO}}} \frac{\partial m_{\mathrm{CaO}}}{\partial t}
$$

with

$$
\begin{aligned}
\frac{\partial m_{\mathrm{CaCO}_{3}}}{\partial t} & =-\frac{M_{\mathrm{CaCO}_{3}}}{M_{\mathrm{CO}_{2}}} \frac{\partial m_{\mathrm{d}}}{\partial t} \\
\frac{\partial m_{\mathrm{CaO}}}{\partial t} & =\frac{M_{\mathrm{CaO}}}{M_{\mathrm{CO}_{2}}} \frac{\partial m_{\mathrm{d}}}{\partial t}
\end{aligned}
$$

where $m_{d}$ is the mass of emitted $\mathrm{CO}_{2}$.

[2] The change of mass of the solid phase is simply equal to the mass of emitted $\mathrm{CO}_{2}$ and equation (9) of Sulem and Famin is corrected as follows:

$$
\frac{\partial m_{\mathrm{s}}}{\partial t}=\frac{\partial m_{\mathrm{CaCO}_{3}}}{\partial t}+\frac{\partial m_{\mathrm{CaO}}}{\partial t}=-\frac{\partial m_{\mathrm{d}}}{\partial t}
$$

Consequently equation (11) of Sulem and Famin becomes

$$
\begin{aligned}
\frac{\partial p}{\partial t}= & \Lambda \frac{\partial T}{\partial t}+\frac{1}{n \rho_{f}\left(\beta_{n}+\beta_{f}\right)} \frac{\partial}{\partial z}\left(\rho_{f} \frac{k_{f}}{\eta_{f}} \frac{\partial P_{p}}{\partial z}\right) \\
& +\frac{1-\rho_{f} \zeta / \rho_{s}}{n \rho_{f}\left(\beta_{n}+\beta_{f}\right)} \frac{\partial m_{d}}{\partial t}
\end{aligned}
$$

with

$$
\zeta=\frac{M_{\mathrm{CaCO}_{3}}}{M_{\mathrm{CO}_{2}}}-\frac{\rho_{\mathrm{CaCO}_{3}}}{\rho_{\mathrm{CaCO}}} \frac{M_{\mathrm{CaO}}}{M_{\mathrm{CO}_{2}}} .
$$

With $M_{\mathrm{CaCO} 3}=100 \mathrm{~g} / \mathrm{mol}, M_{\mathrm{CaO}}=56 \mathrm{~g} / \mathrm{mol}, M_{\mathrm{CO} 2}=44 \mathrm{~g} / \mathrm{mol}$, $\rho_{\mathrm{CaCO} 3}=2.71 \mathrm{~g} / \mathrm{cm}^{3}$ and $\rho_{\mathrm{CaO}}=3.35 \mathrm{~g} / \mathrm{cm}^{3}, \zeta=1.24$.

[3] The governing equations (equations (19) of Sulem and Famin) are changed accordingly

$$
\begin{aligned}
\frac{\partial p}{\partial t}= & \Lambda \frac{\partial T}{\partial t}+\frac{1}{n\left(\beta_{n}+\beta_{f}\right)} \frac{\partial}{\partial z}\left(\frac{k_{f}}{\eta_{f}} \frac{\partial P_{p}}{\partial z}\right)+\frac{1-\rho_{f} \zeta / \rho_{s}}{n \rho_{f}\left(\beta_{n}+\beta_{f}\right)} \frac{\partial m_{d}}{\partial t} \\
\frac{\partial T}{\partial t}= & \frac{1}{\rho C} \frac{\partial}{\partial z}\left(k_{T} \frac{\partial T}{\partial z}\right)+\frac{1}{\rho C} f\left(\sigma_{n}-\frac{1}{h} \int_{0}^{h} P_{p}(\xi, t) d \xi\right) \frac{\partial v}{\partial z} \\
& -\frac{(1-n)}{\rho C} \frac{\Delta_{r} H_{T}^{0}}{M_{C a O_{3}}} \rho_{s} A \exp \left(-\frac{E_{a}}{R T}\right)
\end{aligned}
$$

The numerical results are not significantly changed. Figure 1 compares the "old" computation (Figure 2 of Sulem and Famin) and the revised one.

[4] The conclusions of the paper are not changed: The endothermic character of the decarbonation reaction limits the co-seismic temperature increase; decarbonation is a source of $\mathrm{CO}_{2}$ that significantly increases the slipweakening effect of thermal pressurization; the pore fluid pressure exhibits an initial phase of increase due to thermal pressurization, then a sudden acceleration of generated pore pressure when the solid decomposition is activated. The increase of permeability limits the pore pressure that reaches a maximum and then decreases. The numerical results reproduce this pore pressure pulse and the initial fault weakening followed by a restrengthening of the shear stress. 


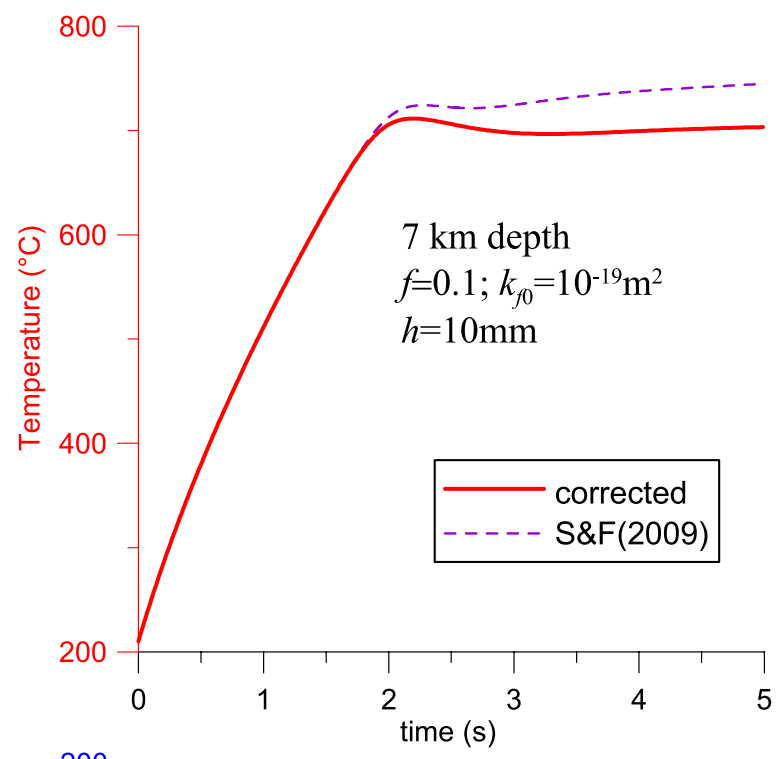

(a)

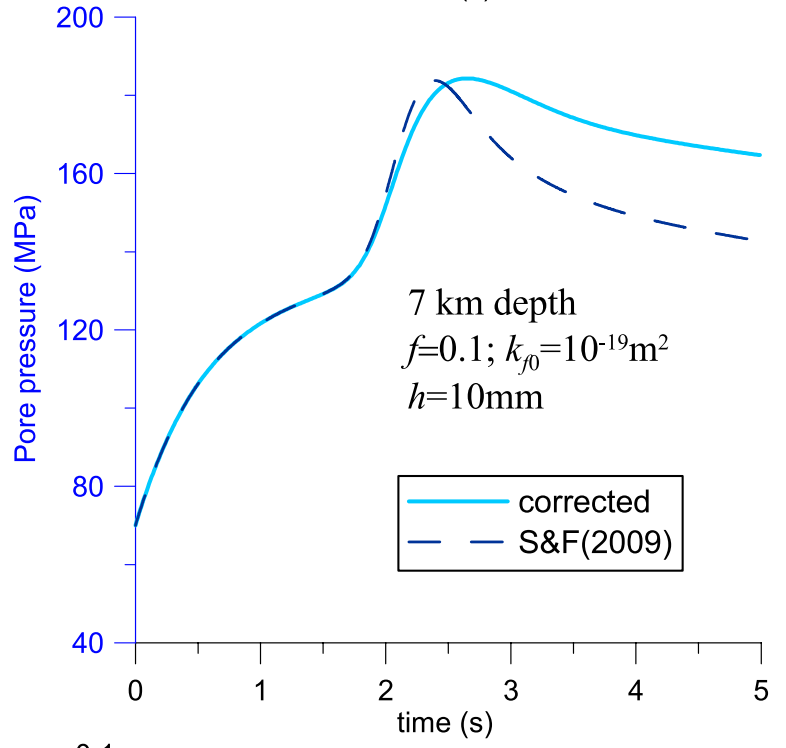

(b)

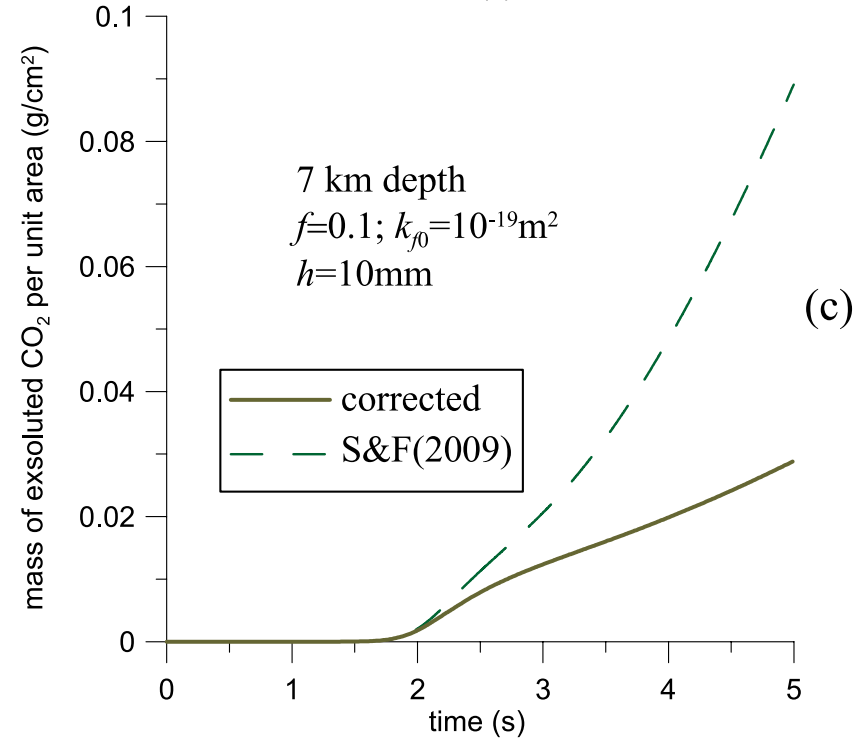

Figure 1. Fault at 7-km depth. Comparison of the corrected computation with the one plotted in Figure 2 of Sulem and Famin (S\&F (2009) in the legend): (a) Evolution of temperature and pore pressure in the center of the shear band, (b) evolution of the shear stress, and (c) evolution of the mass of emitted $\mathrm{CO}_{2}$. 